
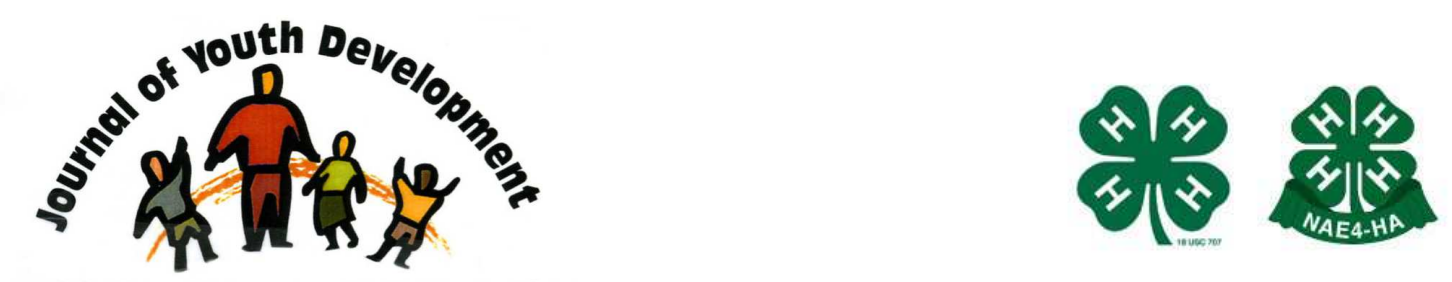

Bridging Research \& Practice

\title{
Youth Voice: Developing Future Leaders
}

\author{
Charla Bading \\ 4-H \& Youth Development \\ Texas A\&M AgriLife Extension Service \\ San Angelo, TX \\ cbading@aq.tamu.edu
}

\author{
Barry L. Boyd \\ Dept. of Agricultural Leadership, Education \& Communications \\ Texas A\&M University \\ College Station, TX \\ b-boyd@tamu.edu
}

\author{
David Lawver \\ Dept. of Agricultural Education \& Communications \\ Texas Tech University \\ David.lawver@ttu.edu \\ Jon Ulmer \\ Dept. of Agricultural Education \& Communications \\ Texas Tech University \\ Jon.ulmer@ttu.edu \\ Chris Boleman \\ 4-H \& Youth Development Program Director \\ Texas A\&M AgriLife Extension Service \\ cboleman@ag.tamu.edu
}




\title{
JOURNAL OF YOUTH DEVELOPMENT \\ bridging research and practice

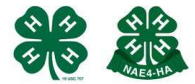

\section{Youth Voice: Developing Future Leaders}

\author{
Charla Bading and Chris Boleman \\ Texas Agrilife Extension Service \\ Barry L. Boyd \\ Texas A\&M University \\ David Lawver and Jon Ulmer \\ Texas Tech University
}

\begin{abstract}
The purpose of this study was to examine youths' perceptions regarding their involvement on youth advisory boards in Cooperative Extension. A stratified, random sample of counties with active youth advisory boards was selected to ensure representation from all Extension districts in the state. A copy of the Involvement and Interaction Rating Scale was mailed to all participants. The findings indicate that youth feel good about their level of participation on their youth advisory board and that adult members of the board allow them to have an active voice in the activities of the board.
\end{abstract}

\section{Introduction and Theoretical Framework}

Youth Engagement...Youth Leadership...Youth Voice...Youth Involvement...Youth-Adult Partnership, are all terms used in youth development to describe the role youth play in youthserving organizations (Zeldin, McDaniel, Topitzes, \& Calvert, 2000). In the context of servicelearning, youth voice refers to the input and decisions young people provide in developing and implementing plans to guide service-learning efforts (Justinianno, Scherer, Johnson, Lewis, Swanson, \& Felix, 2001). Jones and Perkins (2005) note that "youth are well informed about their neighborhoods and can serve as worthy contributors when working with adults as community partners" (para. 1). However, youth voice is often missing in community programs because adults are unaware of what the term means.

\section{Why is Youth Voice Important?}

When youth and adults engage as partners in the decision-making process, both groups benefit. Billing (2000) observed that youth related outcomes are increased when youth are 
given responsibility for planning, implementing, and evaluating their own learning. Avolio and Vogelgesang (2011) note that having a variety of meaningful leadership roles and experiences early in life leads to later emergence as a leader. The Innovation Center for Community at the University of Wisconsin-Madison states that including youth in the decision-making process also has a positive effect on adults (Zeldin, et al., 2000).

\section{Youth-Adult Relationships within Programs}

Only a few scholars have presented models to show how youths' skills can be utilized in youth development programming. Hart's (1992) Ladder of Childrens' Participation assesses where young people stand in relation to adults in the area of project development, as well as where organizations stand in this regard. Hart outlines three non-participatory levels:

1. Manipulation: Children participate, but have no understanding of the issues and do not understand their actions.

2. Decoration: Children are there to entertain or look good, but they have little understanding of the purpose and no say in organizing the event.

3. Tokenism: Children are given a voice, but they have little choice about the subject or the style of communication and little opportunity to develop opinions. (1992, p. 9)

The final four levels of participation on Hart's ladder involve different kinds of adult-youth arrangements. Hart notes that for a project to be considered participatory, the following requirements should be met:

- Youth understand the intentions of the project,

- They know who impacted the decisions concerning involvement,

- They have a role with a purpose,

- They volunteer to be part of the project after they know what the project entailed. (1992, p. 11)

Hart refers to adult initiated projects involving shared decisions with youth as "true participation." Hart comments that "projects like these...are all too rare" and attributes this to "the absence of caring adults attuned to the particular interests of young people" (1992, p. 14).

Mitra (2000) developed a pyramid model that shows a hierarchy of three varying forms of youth voice: information, collaboration, and autonomy. Her research focused on junior and senior high school students involved in educational change. The information level illustrates the minimal and most common form of involvement, where youth share ideas with adults who interpret the data without youth input. Collaboration describes where youth and adults work together to identify problems, interpret the data, and implement an action plan to promote change. Youth independently design and implement plans in the autonomy stage. Mitra's model demonstrates that youth voice can be invited and utilized in various forms, thus allowing students to serve as respected contributors in youth-adult partnerships.

Jones and Perkins (2005) designed a continuum that is based on an extensive review of literature. The Continuum of Youth-Adult Relationships five-stages include: adult-centered leadership, adult-led collaboration, youth-adult partnership, youth-led collaboration, and youthcentered leadership. In the first stage, youth have no voice. As programs progress through the stages, the level of youth voice increases. This study uses the Involvement and Interaction Rating Scale which is based on this model (Jones \& Perkins, 2005). 
Research shows that when young people work with adult volunteers:

- youth programs become more successful and have a greater impact on youth's ability to communicate, solve problems, and work effectively with others; and

- youth mature and become more responsible (Boleman \& Burkham, 2005).

Thus, it is important for young people to be involved with adults in developing, implementing, and evaluating programs for youth.

\section{Youth Perceptions of Adults}

Several studies have focused on the influence of youth-adult relationships and the influence on the attitudes of youth. Lynch and Cicchetti (1997) examined youths' awareness of their relationship with adults. They asked 1,226 low-risk elementary and middle school children, ages 7 to 15, about four different relationship partners: mother, best friend, teacher, and classmates. The relationship with teachers was rated lowest by students of the four relationships (Lynch \& Cicchetti, 1997).

This gap between youth and adults appears to be widening due to the lack of opportunities for youth-adult partnerships. Traditional program structures where youth are "receivers" and adults are the providers still seems to be the norm (Lynch \& Cicchetti, 1997). As youth skills grow and develop, they need the opportunity for more decision-making power; thus, traditional program structure tends to preserve the impression that adults are in charge and not interested in youth voice. This discourages youth who want to be contributors in community programs and bond with adults. (Lynch \& Cicchetti, 1997).

Social contact between youth and adults can lead to more positive perceptions and reduced prejudices (Allport, 1954). Caspi (1984) evaluated the effect of intergroup contact on attitudes, by comparing children attending a traditional preschool to children attending an age integrated school, which included a large number of elderly substitute teachers. The children at the ageintegrated school, in direct contact with older adults, held a more favorable attitude towards the elderly than children who attended the preschool without elderly teachers.

\section{Purpose and Objectives}

The purpose of this study was to examine the perceptions and experiences of youth engaged in youth-adult relationships within Extension programs. The study was guided by the following objectives:

1. Describe the demographic characteristics youth members on the youth board.

2. Assess the perceptions of youth toward their involvement with one another as youth board members.

3. Assess the youths' perceptions regarding how they are treated by adult members of the youth board.

\section{Methodology}

The Texas AgriLife Extension Service requires that each county create an advisory committee called a Youth Board. The Youth Board is a program area committee that meets face-to-face at least twice annually. Membership on the Board consists of eight to ten members, comprised one-half youth and one-half adults. Youth members are typically $14-18$ years old (Boleman, \& Burkham, 2005). 
The Youth Board is responsible for reviewing yearly educational impacts and helping to decide how task forces/coalitions can address priority issues. Additionally, the group plans outreach efforts to new youth audiences and looks at new projects for implementation in the county $4-\mathrm{H}$ program (Boleman, \& Burkham, 2005).

\section{Population and Sample}

The population for this study consisted of all county Youth Boards in the Texas AgriLife Extension Service. A purposeful cluster sample was chosen for this study. The Texas Extension Service is divided into four regions. Each of the four regions consists of 3 districts with approximately 20 counties in each district. Each region has four 4-H Regional Program Directors who were asked by the researcher to identify nine counties within their region that qualified for the study. Only those counties who met the following criteria were selected:

1. County is fully staffed, and has had no vacancies within the previous year.

2. County has a Youth Board in place.

Once the counties were selected, the county Extension agent(s) in each county was contacted and informed of their selection. Of the 36 counties asked to participate, the researcher received surveys back from 31 counties.

\section{Instrumentation}

The Involvement and Interaction Rating Scale (Jones, 2004) was used to assess youth perception of their involvement as pertaining to participation on a Texas AgriLife Extension Service Youth Board. This instrument was developed to identify characteristics and attitudes of individuals participating in adult and youth partnerships. A 10-point, interval scale was utilized to assess the given constructs set by the instrument. Bipolar statements were used to measure the perceptions of each participant's experience.

Jones (2004) established the initial reliability of the instrument, reporting a Cronbach Coefficient Alpha of .94. The authors ran a Cronbach Coefficient Alpha reliability coefficient for each scale with the following results: Youth Involvement (.87) and Adult Involvement (.72). By removing question 2 from the adult involvement scale, the reliability was improved from .72 to .82. The Cronbach Coefficient Alpha reliability coefficient for the Youth-Adult interaction scale was .87.

\section{Data Collection and Analysis}

The Involvement and Interaction Rating Scale rates relationship quality on a 10-point scale. The scale intervals were 1 to 2 (very poor); 3 to 4 (poor); 5 to 6 (fair); 7 to 8 (good); 9 to 10 (excellent). The 38-item rating scale included bipolar statements (i.e., positive and negative) to measure participants' perceptions of their experiences. Negative statements were reverse coded for analysis.

The original response date to complete the survey and return it to the researcher was September 15, 2011. Eighty-seven surveys were received by the early deadline. Nine surveys were received after the early deadline. No significant differences or response error was found between early responders and late responders at the $p<.05$ level.

\section{Findings}

Objective one was to describe the demographic characteristics of the Texas AgriLife Extension Service Youth Board youth members which are presented in Table 1. Approximately $65 \%$ of 
the participants were female. Due to the limited number of responses in the 12 and under category, this group was combined with the 13-14 age group to make the 14 and under group. The 17-18 year old group had the most responses to the survey with the groups 14 and under and 15-16 being very close in percent of survey responses. Ninety percent of the respondents were Anglo; however, non-Anglo ethic groups, including Asian, Black, Hispanic and Native American, were represented. Fifty-nine percent of the participants lived in areas with less than 10,000 population, defined as town with fewer than 10,000 populations and rural non-farm or farm (rural area where agricultural products are sold). The other $16 \%$ represented either: Town/City 10,000-50,000 population and its suburbs, Suburb of city more than 50,000 populations, or Central city more than 50,000 populations. Because of the small number of responses Town/City, Suburb and Central City were combined to represent the populations greater than 10,000 category.

Table 1

Demographics characteristics of Youth Board youth participants $\mathrm{N}=75$

\begin{tabular}{|c|c|c|}
\hline \multicolumn{2}{|c|}{ Number } & Percent \\
\hline Gender & 51 & 68.0 \\
\hline Female & 24 & 32.0 \\
\hline Male & 17 & 22.7 \\
\hline Age & 21 & 28.0 \\
\hline 14 and under & 37 & 49.3 \\
\hline $15-16$ & \multicolumn{2}{|l}{} \\
\hline $17-18$ & 68 & 90.7 \\
\hline Ethnicity & 7 & 9.3 \\
\hline Anglo & \multicolumn{2}{|}{} \\
\hline Non-Anglo & 59 & 78.7 \\
\hline Resident & 16 & 21.3 \\
\hline Population $<10,000$ & & \\
\hline Population $>10,000$ & & \\
\hline
\end{tabular}

Objective two examined the perceptions of youth toward their involvement with one another as youth board members. Table 2 gives the mean score for each of the questions related to youth perception of their own involvement. The lowest mean score (6.61) is for the question related to "youth rely on themselves to make key decisions." The bipolar statement related to this question is, "youth make few decisions for themselves, often relying on the decisions of adults." The question "youth have an equal vote in the decision-making process" has the highest mean score of 8.53. The overall mean score for youth serving on the Youth Board for the youth perception of their own involvement indicator questions is 7.91, which indicates they felt good about their involvement on the Board. 


\section{Table 2}

Scale item means and scale mean score for youth participants on county Youth Boards $\mathrm{N}=75$

\begin{tabular}{|l|c|}
\hline Question & Mean \\
\hline $\begin{array}{l}\text { Youth have full access to information that is needed to make } \\
\text { decisions. }\end{array}$ & 8.56 \\
\hline $\begin{array}{l}\text { Youth have an equal vote in the decision-making process. } \\
\text { Youth always have the opportunity to discuss their concerns } \\
\text { about group decisions. }\end{array}$ & 8.53 \\
\hline $\begin{array}{l}\text { Youth help one another in developing new skills. } \\
\text { Youth frequently share ideas that matter to them. }\end{array}$ & 8.48 \\
\hline Youth are very excited about their involvement with this project. & 8.48 \\
\hline Youth take lots of initiative in working on projects. & 8.28 \\
\hline Youth arrive to meetings/events on time. & 8.11 \\
\hline $\begin{array}{l}\text { Youth are given major responsibilities for specific tasks or } \\
\text { assignments. }\end{array}$ & 7.88 \\
\hline $\begin{array}{l}\text { Youth are very concerned with community change. } \\
\text { Youth are fully committed to their duties. }\end{array}$ & 7.88 \\
\hline Youth rely on themselves to make key decisions. & 7.57 \\
\hline Overall Mean & 7.40 \\
\hline
\end{tabular}

Note: The scale ranges from: 1-2 (very poor); 3-4 (poor); 5-6 (fair); 7-8 (good); 9-10 (excellent). Table presents positive aspect of each question.

A t-test was used to determine if significant differences existed in perceptions of youth involvement between gender, ethnicity and residence. As shown in Table 3, males were more positive than females on their ratings of youth involvement (mean of 8.03 and 7.84, respectively), but the differences were not significant at $p<.05$. Even though there was no significant difference between white and non-Anglo participants or population $<10,000$ and population $>10,000$, the table also shows that both Anglo members and those that reside in population $<10,000$ areas are more positive when ranking youth involvement. 
Table 3

Youth Board youth member's perception by gender, ethnicity and resident of their own involvement $\mathrm{N}=75$

\begin{tabular}{|c|c|c|c|c|c|c|}
\hline & $\boldsymbol{N}$ & $\boldsymbol{M}$ & $\boldsymbol{S D}$ & $\boldsymbol{t}$ & $\boldsymbol{d f}$ & $\boldsymbol{*}_{\boldsymbol{p}}$ \\
\hline Gender & & & & & & \\
\hline Female & 51 & 7.84 & 1.16 & 0.67 & 73 & .50 \\
\hline Male & 24 & 8.03 & 0.99 & & & \\
\hline Ethnicity & & & & & & \\
\hline Anglo & 68 & 7.92 & 1.12 & 0.31 & 73 & .75 \\
\hline Non-Anglo & 7 & 7.78 & 1.01 & & & \\
\hline Resident & & & & & & \\
\hline $\begin{array}{c}\text { Population }<10,000 \\
\text { Population }>10,000\end{array}$ & 59 & 7.93 & 1.10 & 0.47 & 73 & .63 \\
\hline
\end{tabular}

Note: The scale ranges from: 1-2 (very poor); 3-4 (poor); 5-6 (fair); 7-8 (good); 9-10 (excellent). The scale has 13 questions to assess youth involvement. ${ }^{*} p<.05$.

An Analysis of Variance (ANOVA) was also employed to test for differences existing between youth participants perception of their own involvement based on age. As shown in Table 4, the one-way ANOVA indicated no significant differences in perception between youth participants by age.

Table 4

Youth Board youth member's perception of their own involvement by age $\mathrm{N}=75$

\begin{tabular}{|l|c|c|c|c|c|}
\hline & $\mathbf{n}$ & $\mathbf{M}$ & SD & F & *p \\
\hline Age & & & & & \\
\hline 14 and under & 17 & 7.94 & 1.16 & 0.13 & .87 \\
\hline $15-16$ & 21 & 7.99 & 1.05 & & \\
\hline $17-18$ & 37 & 7.95 & 1.13 & & \\
\hline
\end{tabular}

Note: The scale ranges from: 1-2 (very poor); 3-4 (poor); 5-6 (fair); 7-8 (good); 9-10 (excellent). The scale has 13 questions to assess youth involvement. ${ }^{*} p<.05$

Objective 3 examined each youths' perception regarding how they were treated by adult members of the youth board. Table 5 gives the mean score for each of the questions related to youth perception of how adults let them be involved. The highest mean score (8.85) indicates adults are very concerned with community change. The overall mean score of youth members of the Youth Board for the youth perception of how adults let them be involved indicator 
questions is 7.82 indicating youth feel like the adult members of the Youth Board allow them to be actively involved at members of the board.

Table 5

Youth Board youth only members adult involvement indicators questions mean and overall mean $\mathrm{N}=75$

\begin{tabular}{|l|c|}
\hline Question & Mean \\
\hline 1. Adults display a willingness to accept and nurture youth leadership. & 8.08 \\
\hline 2. Adults display a tendency to want to guide youth. & 6.28 \\
\hline 3. Adults always listen to the suggestions of youth. & 7.77 \\
\hline $\begin{array}{l}\text { 4. Adults never totally take over everything when working on project } \\
\text { activities. }\end{array}$ & 7.24 \\
\hline 5. Adults learn new skills from one another. & 7.80 \\
\hline 6. Adults always take the ideas of youth seriously. & 7.67 \\
\hline 7. Adults encourage youth to come up with their own ideas. & 8.49 \\
\hline 8. Adults are very excited about being involved with the project. & 8.16 \\
\hline 9. Adults are very concerned with community change. & 8.85 \\
\hline Overall Mean & $\mathbf{7 . 8 2}$ \\
\hline
\end{tabular}

Note: The scale ranges from: 1-2 (very poor); 3-4 (poor); 5-6 (fair); 7-8 (good); 9-10 (excellent). Table represents positive aspect of questions.

A t-test determined if significant differences existed in youth perceptions of how involved adults let them be on the board based on gender, ethnicity and residence. As shown in Table 6, both female and male participants had positive feelings in regards to how involved adults allow them to be as members of the youth board; however, females were more positive than males on their ratings of youth involvement (mean of 8.03 and 7.95, respectively). However, the differences were not statistically different at the .05 level. The table also shows that both Anglo members and those that reside in population $<10,000$ areas are more positive than non-Anglo and population $>10,000$ when ranking how involved adult let youth be involved, yet the means are not statistically different. 


\section{Table 6}

Youth member's perception by gender, ethnicity and residence of how involved adults let them be $\mathrm{N}=75$

\begin{tabular}{|c|c|c|c|c|c|c|}
\hline & $\boldsymbol{N}$ & $M$ & $S D$ & $t$ & $d f$ & $* p$ \\
\hline \multicolumn{7}{|l|}{ Gender } \\
\hline Female & 51 & 8.03 & 1.22 & 0.26 & 73 & .79 \\
\hline Male & 24 & 7.95 & 1.23 & & & \\
\hline \multicolumn{7}{|l|}{ Ethnicity } \\
\hline Anglo & 68 & 8.01 & 1.23 & 0.18 & 73 & .85 \\
\hline Non-Anglo & 7 & 7.92 & 1.11 & & & \\
\hline \multicolumn{7}{|l|}{ Resident } \\
\hline Population $<10,000$ & 59 & 8.05 & 1.19 & 0.60 & 73 & .54 \\
\hline Population > 10,000 & 16 & 7.84 & 1.32 & & & \\
\hline
\end{tabular}

Note: The scale ranges from: 1-2 (very poor); 3-4 (poor); 5-6 (fair); 7-8 (good); 9-10 (excellent).

The scale has 9 questions to assess adult involvement. ${ }^{*} p<.05$.

An analysis of variance (ANOVA) was also employed to test for differences youth perceptions by age group, on how involved they feel adults on the Youth Board allow them to be in decision making. As shown in Table 7, the one-way ANOVA indicated no significant differences between youth participants' perceptions by age.

Table 7

Youth member's perception of how involved adults allow them to be with the Youth Board by age $\mathrm{N}=75$

\begin{tabular}{|l|c|c|c|c|c|}
\hline & $\boldsymbol{n}$ & $\boldsymbol{M}$ & $\boldsymbol{S D}$ & $\boldsymbol{F}$ & * $\boldsymbol{p}$ \\
\hline Age & & & & & \\
\hline 14 and under & 17 & 7.87 & 0.96 & .15 & .85 \\
\hline $15-16$ & 21 & 8.01 & 1.37 & & \\
\hline $17-18$ & 37 & 8.06 & 1.25 & & \\
\hline
\end{tabular}

Note: The scale ranges from: 1-2 (very poor); 3-4 (poor); 5-6 (fair); 7-8 (good); 9-10 (excellent). ${ }^{*} p<.05$.

\section{Conclusions}

The Involvement and Interaction Rating Scale measured youths' perception of their involvement on the youth board as well as their perceptions regarding how involved adults allow them to be. The overall mean score of the youth members of the Youth Board for the perception of their 
own involvement indicator questions is 7.90. This score indicates that youth demonstrated high levels of youth voice and decision making, responsibility, and commitment to the project. The overall mean score for their perception of how adults let them be involved is 7.81. This indicates that adult show support through their commitment to nurture youth voice and decision making and dedication to the project.

Because the Involvement and Interaction Rating Scale cannot be matched directly to the five stages in Jones and Perkin's Continuum of Youth-Adult Relationships, it is difficult to state what a "good" relationship actually means. It could describe anything from a Youth-Adult Partnership to Youth-Centered Leadership (2005). The authors believe that most of the youth experienced, at minimum, a Youth-Adult Partnership. It is suggested that future research include a qualitative component that asks the youth and adults to openly describe behaviors of the Youth Board in order to better determine the true stage of their relationship.

The findings of this study also indicate the youth participating in Extension Youth Boards are experiencing leadership roles where they make significant decisions; thus, providing them with those early life experiences that will help them become effective leaders (Avolio \& Vogelgesang, 2011).

Even though the overall mean scores for youth involvement (7.90) and adult involvement (7.81) lead the researchers to conclude that the youth members feel good about their involvement on the Youth Board, there is nothing in this study that describes why they feel that way or why they feel or don't feel excellent (scoring a 9-10) about their involvement. Scores in this range might indicate a true Youth-Centered Leadership program (Jones \& Perkins, 2005). Further studies need to be conducted to determine what action steps to help youth programs reach this ideal level. The findings described here were limited by the sample size and population and cannot be generalized to the larger population.

Although the findings in this study lead the researcher to conclude that youth serving on these Youth Boards had a positive experience, there are things Extension should keep in mind as they continue to involve youth in leadership positions.

- Youth should be involved in the program development process from the beginning. Don't ask youth to get involved after the adults have made all of the decisions. Respect young people as equal partners in decision making by making sure they are given significance tasks in planning, implementing and evaluating programs.

- Avoid tokenism when incorporating youth into all relevant Extension committees and task forces. Don't appoint two youth to a committee with a large number of adults and expect a true youth-adult partnership.

- Share ideas with youth, but don't make all of the decisions for them. Youth will develop stronger leadership skills if given opportunities to succeed as well as to fail, thus teaching them to see and accept the consequences of their decisions. This supports Bruce, Webster, and Hoover's (2006) findings that teens feel that adults often overshadow their own participation.

- Implement practices such as training youth and adults in leadership and facilitation, using asset based approaches, and reflection as a tool for both youth and adults (Camino, 2005). 


\section{References}

Allport, G.W. (1954). The nature of prejudice. New York, NY: Doubleday Books.

Avolio, B.J., \& Vogelgesang, G. (2011). Beginnings matter in genuine leadership development. In S.E. Murphy, \& R.J. Reichard (Eds.), Early development and leadership: Building the next generation of leaders, (pp. 179-204). New York: Psychology Press/Routledge.

Billing, S.H. (2000). Research on K-12 school-based service-learning: The evidence builds. Phi Delta Kappan, 81(9), 658-664.

Boleman, C., \& Burkham, A. (2005). Volunteer administration in the 21st century. Texas Cooperative Extension, College Station Texas. Publication \#D-1452.

Bruce, J.A., Webster, N.S., \& Hoover, T.S. (2006). Developing youth voice in service-learning projects. Journal of Extension [Online], 44(4). Article 4TOT1. Available at:

http://www.joe.org/joe/2006august/tt1.php

Caspi, A. (1984). Contact hypothesis and inter-age attitudes: A field study of cross age contact. Social Psychology Quarterly, 47, 74-80.

Camino, L. (2005). Youth-led community building: Promising practices from two communities using community-based service-learning. Journal of Extension [Online], 43(1). Article 1FEA2. Available at: http://www.joe.org/joe/2005february/a2.php

Hart R. (1992). Children's Participation: From tokenism to citizenship, Innocenti Essays No. 4. New York, NY: UNICEF.

Innovation Center for Community and Youth Development. (2003). Youth adult partnerships: $A$ training manual. Takoma Park, MD: Innovation Center for Community and Youth Development.

Jones, K.R. (2004). An assessment of perceptions and experiences in community-based youth adult relationships. Unpublished doctorate dissertation. Pennsylvania State University, University Park, PA.

Jones, K.R., \& Perkins, D.F. (2005). Determining the quality of youth-adult relationships within community based youth programs. Journal of Extension [Online], 43(5). Article 5FEA5. Available at: http://www.joe.org/joe/2005october/a5p.shtml

Justinianno, J., Scherer, C., Johnson, L., Lewis, B., Swanson, R., \& Felix, A. (2001). Youth voice: A guide for engaging young people in leadership and decision-making in service-learning programs. Points of Light Foundation.

Lynch, M., \& Cicchetti, D. (1997). Children's relationships with adults and peers: An examination of elementary and junior high school students. Journal of School Psychology, 35, 81-100.

Mitra, D.L. (2000). Opening the floodgates: Giving students a voice in school reform. Forum. United Kingdom. 
Zeldin, S., McDaniel, A., Topitzes, D., \& Calvert, M. (2000). Youth in decision-making: $A$ study on the impact of youth on adults and organizations. A report developed by the University of Wisconsin-Madison and the Innovation Center for Community and Youth Development, Chevy Chase, MD.

(C) Copyright of Journal of Youth Development Bridging Research and Practice. Content may not be copied or emailed to multiple sites or posted to a listserv without copyright holder's express written permission. Contact Editor at: patricia.dawson@oregonstate.edu for details. However, users may print, download or email articles for individual use. ISSN 2325-4009 (Print); ISSN 2325-4017 (Online) 